\title{
PENGARUH EMISI UDARA PADA SENTRA PENGOLAHAN BATU KAPUR TERHADAP KAPASITAS VITAL PARU PEKERJA DAN MASYARAKAT DI DESA KARAS KECAMATAN SEDAN KABUPATEN REMBANG
}

\author{
Siti Rachmawati (1), M. Masykuri (1,2), Sunarto (1,3) \\ (!) Program Magister Ilmu Lingkungan Program Pascasarjana UNS \\ E-mail : rachmauns@gmail.com
}

\section{ABSTRAK}

Pengolahan batu kapur di Kabupaten Rembang mempunyai dampak positif yaitu terbukanya lapangan pekerjaan bagi masyarakat. Di pihak lain timbul dampak negatif terhadap kesehatan masyarakat dan pekerja karena emisi gas buang yang dihasilkan pada proses pengolahan dan kualitas lingkungan menurun yang ditandai adanya pencemaran udara. Penelitian ini bertujuan untuk mengetahui kualitas udara pada sentra pengolahan batu kapur dan pengaruh emisi udara pada pengolahan batu kapur terhadap kapasitas vital paru pekerja dan masyarakat.

Jenis penelitian ini merupakan penelitian diskriptif analitik. Penelitian dilakukan pada pengolahan batu kapur Desa Karas, Kecamatan Sedan, Kabupaten Rembang. Pengambilan sampel udara ambien difokuskan pada 3 zona yang dibagi menjadi 6 titik pada pengolahan batu kapur. Uji kualitas udara ambien diuji di Laboratorium Pusat MIPA Universitas Sebelas Maret Surakarta. Teknik sampling responden menggunakan teknik purposive sampling sehingga sampel yang menjadi objek penelitian berjumlah 73 orang laki-laki. Teknik pengolahan dan analisis data untuk mengetahui pengaruh emisi udara terhadap kapasitas vital paru dilakukan dengan uji statistik Chi Square Test, Kruskall Wallis dan Odds Ratio.

Hasil penelitian menunjukkan bahwa kualitas udara pada sentra pengolahan batu kapur berdasarkan PP No 41 Tahun 1999 adalah melebihi baku mutu untuk gas CO dan debu. Gas $\mathrm{NO}_{2}$ dan $\mathrm{SO}_{2}$ masih dinyatakan di bawah baku mutu. Terdapat pengaruh antara emisi udara terhadap kapasitas vital paru pada pekerja dan masyarakat untuk parameter debu (Odds Ratio $p=0,033$ dan $O R=1,584$ ) dan gas $C O$ (Odds Ratio $p=0,000$ dan $O R=2,558$ ), sedangkan $\mathrm{NO}_{2}$ dan $\mathrm{SO}_{2}$ tidak mempengaruhi kapasitas vital paru.

\section{Kata kunci : Emisi Udara, Batu Kapur, Kapasitas Vital Paru}

\section{PENDAHULUAN}

Pembangunan merupakan kegiatan untuk mengelola dan memanfaatkan sumberdaya guna meningkatkan mutu kehidupan rakyat. Pembangunan yang berwawasan lingkungan telah diterima sebagai suatu prinsip Pembangunan Nasional dengan berbagai peraturan pelaksanaannya. Dalam rangka mewujudkan pembangunan yang berkelanjutan di Kabupaten Rembang diperlukan perencanaan yang terpadu, melibatkan semua dinas yang terkait dalam pengelolaan lingkungan hidup dan sumberdaya alam. Salah satu sumberdaya alam yang ada di Kabupaten Rembang memerlu pengelolaan yang terpadu adalah batu kapur. Pengolahan batu kapur di Kabupaten Rembang mempunyai dampak yang positif dan negatif kepada masyarakat dan lingkungannya. Dampak positifnya yaitu terbuka lapangan pekerjaan bagi masyarakat dan dampak negatifnya terhadap kesehatan karena emisi gas buang yang dihasilkan pada proses pengolahan batu kapur tersebut. Yulaekah (2007), menyatakan bahwa 60 pekerja di industri batu kapur di Desa Mrisi Kecamatan Tanggungharjo Kabupaten Grobogan diperoleh hasil lebih dari $50 \%$ pekerja mengalami gangguan fungsi paru dengan kategori obstruksi ringan, sedang dan berat, sedangkan menurut Subijanto (2008) menyatakan bahwa jarak tempat tinggal penduduk dengan sumber paparan debu gamping merupakan factor risiko bagi kejadian obstruktif dan restriktif paru.

Salah satu sentra industri batu kapur di Kabupaten Rembang terletak di Desa Karas Kecamatan Sedan. Berdasarkan pengamatan 
terhadap pekerja, hampir seluruh pekerja tidak menggunakan Alat Pelindung Diri seperti masker, sarung tangan, sepatu boot dan kacamata. Selain itu, masyarakat mengeluh sering mengalami sesak nafas, dan batuk-batuk. Pembakaran batu kapur yang sering disebut jobong terletak di tengah pemukiman penduduk, pada saat produksi debu sangat tebal disertai asap hitam yang mengepul. Bahan bakar yang digunakan adalah ban bekas dan kayu. Pengolahan batu kapur di Desa Karas merupakan industri informal yang dikelola oleh masyarakat dengan teknologi yang masih sederhana, tanpa banyak tersentuh oleh peraturan perundangan.

Udara tidak pernah bersih tetapi selalu mengandung partikel-partikel asing yang jika konsentrasinya terlalu tinggi dapat menyebabkan kualitas udara berkurang atau tidak berfungsi sesuai peruntukannya. Hal ini tercantum dalam Keputusan Menteri Negara Kependudukan dan Lingkungan Hidup No. 02/ MENKLH/ 1988, yang menyatakan bahwa pencemaran udara, adalah masuk atau dimasukkannya makhluk hidup, zat, energi dan/atau komponen lain ke dalam udara dan/atau berubahnya tatanan (komposisi) udara oleh kegiatan manusia atau proses alam, sehingga kualitas udara menjadi kurang atau tidak dapat berfungsi lagi sesuai dengan peruntukannya. Berdasarkan asal dan kelanjutan perkembangannya di udara, pencemar udara dibedakan menjadi 2 yaitu pencemar udara primer dan pencemar udara sekunder (Kristanto, 2001).

Pencemaran udara dapat mengakibatkan peradangan paru dan jika hal ini berlangsung terus-menerus dapat mengakibatkan penurunan kapasitas vital paru, yang akhirnya dapat meningkatkan kelainan faal paru obstruktif. Bahan pencemar udara yang dapat menyebabkan kelainan pada saluran pernapasan jika bahan pencemar tersebut dihirup dari udara ambien antara lain adalah gas $\mathrm{SO}_{2}, \mathrm{O}_{3}, \mathrm{NO}_{2}$ dan partikel debu. Gas yang paling berbahaya bagi paru-paru adalah $\mathrm{SO}_{2}$ dan $\mathrm{NO}_{2}$. Kalau unsur ini dihisap, maka berbagai keluhan di paru-paru akan timbul dengan nama CNSRD (chronic non spesific respiratory disease) seperti asma dan bronkhitis (Aditama, 1992).

Chattopadhyay BP et al., (2005) menyatakan bahwa siswa sekolah di kota metro Kolkata India telah mengalami berbagai gejala pernapasan daripada siswa sekolah di pedesaan hal ini dikarenakan sebagian besar sekolah-sekolah di kota metro India terletak di pinggir jalan lalu lintas.

Sugiarti (2009) menyatakan bahwa pengaruh gas pencemar udara terhadap kesehatan manusia dapat berakibat langsung maupun tidak langsung seperti merusak susunan hemoglobin darah, penyakit ispa, iritasi tenggorokan, penyakit pneumokinosis, kardiovaskuler dan kanker.

Penelitian ini bertujuan untuk mengetahui kualitas udara pada pengolahan batu dan pengaruh emisi udara pada pengolahan batu kapur terhadap kapasitas vital paru pekerja dan masyarakat di Desa Karas Kecamatan Sedan Kabupaten Rembang.

\section{METODE PENELITIAN}

Jenis penelitian ini merupakan penelitian diskriptif analitik. Penelitian dilakukan pada bulan Oktober 2012 dan bertempat pada pengolahan batu kapur di Desa Karas, Kecamatan Sedan, Kabupaten Rembang. Emisi udara diuji di Laboratorium Pusat MIPA Universitas Sebelas Maret Surakarta.

Populasi penelitian ini adalah pekerja pengolahan batu kapur dan masyarakat yang berada di sentra pengolahan batu kapur (dengan jarak 15-500 meter dari tobong pembakaran) di Desa Karas, Kecamatan Sedan, Kabupaten Rembang.

Pengambilan sampel dengan teknik purposive sampling. Purposive sampling adalah teknik penentuan sampel dengan pertimbangan tertentu (Sugiyono, 2002). Dengan kata lain, sampel penelitian ini ditentukan oleh peneliti menurut pertimbangan kriteria tertentu yang telah ditetapkan sebelumnya. Untuk mendapatkan sampel yang eligible atau yang memenuhi syarat penelitian maka diterapkan kriteria inklusi dan eksklusi.

Pengumpulan data dalam penelitian ini diperoleh dari 2 (dua) sumber data yaitu data primer, data yang didapat langsung dari lapangan dengan menggunakan kuesioner melalui wawancara serta pengukuran terhadap responden dan data sekunder diperoleh melalui dokumen-dokumen yang ada di Balai Desa Karas dan Puskesmas Kecamatan Sedan.

Tahap pengolahan data yang pertama yaitu editing, dimaksudkan untuk melakukan pengecekan kelengkapan data, kesinambungan data dan keseragaman data, yang kedua koding, 
dilakukan setelah editing, langkah selanjutnya adalah melakukan pengkodean data untuk memudahkan pengolahannya. Ketiga adalah data dimasukkan, data yang telah dilakukan koding dimasukkan ke dalam Variabel Sheet SPSS, sedangkan yang terakhir adalah tabulasi. Tabulasi merupakan langkah untuk mengelompokkan data ke dalam suatu data tertentu menurut sifat-sifat yang dimiliki.

Analisis data dilakukan dengan menggunakan Software Program SPSS. Hasil penelitian kemudian dianalisis secara deskriptif. Nilai signifikansi dipergunakan sebagai dasar hitungan bagi setiap uji statistik pada masing-masing variabel terikat, yaitu emisi udara terhadap kapasitas vital paru serta pengaruhvariabel pengganggu seperti riwayat penyakit, riwayat pekerjaan, jenis kelamin, umur, masa kerja, kebiasaan olahraga, status gizi, kebiasaan olahraga dan lama paparan terhadap kapasitas vital paru pekerja industri batu kapur. Uji statistik regresi logistik dipergunakan untuk mengetahui hubungan antara variabel bebas terhadap variabel terikat dengan langkah-langkah sebagai berikut yaitu analisis univariat, bivariat dan multivariate.

\section{HASI L DAN PEMBAHASAN}

Desa Karas merupakan salah satu dari 21 desa yang ada di Kecamatan Sedan, Kabupaten Rembang. Desa Karas terletak di sebelah timur dari ibukota Kabupaten dan berjarak $\pm 30 \mathrm{Km}$ dari ibukota Kabupaten.Pengambilan sampel dibagi 4 zona yang dijadikan 6 titik, hal ini dikarenakan mempertimbangkan beberapa hal yaitu letak tobong gamping tidak terpusat satu tempat melainkan menyebar dan arah angin yang berubah-ubah. Hasil pengukuran emisi udara di pengolahan batu kapur Desa Karas Kecamatan Sedan Kabupaten Rembang yang dilakukan pada 4 zona dan dibagi menjadi 6 titik, terlihat pada tabel 1 .

Rata-rata konsentrasi $\mathrm{SO}_{2}$ hasil pengukuran di 6 titik pengolahan batu kapur Desa Karas Kecamatan Sedan Kabupaten Rembang sebesar 1,782 $\mu \mathrm{g} / \mathrm{Nm}^{3}$. Konsentrasi minimun sebesar $0,067 \mu \mathrm{g} / \mathrm{Nm}^{3}$ (di titik 6 yaitu zona 4 masyarakat sekitar) dan konsentrasi maksimum 6,115 $\mu \mathrm{g} / \mathrm{Nm}^{3}$ (di titik 2 yaitu tobong 2). Dengan demikian rata-rata konsentrasi $\mathrm{SO}_{2}$ pada 6 titik berada di bawah baku mutu yang ditetapkan pada PP No 41 Tahun 1999 yaitu $900 \mu \mathrm{g} / \mathrm{Nm}^{3}$. Melihat hasil pengukuran konsentrasi $\mathrm{SO}_{2}$ dari 6 titik ternyata semua konsentrasinya berada di bawah NAB. Semua titik menunjukkan bahwa $\mathrm{SO}_{2}$ masih di bawah baku mutu hal ini dikarenakan dalam pembakaran batu kapur menghasilkan gas $\mathrm{SO}_{2}$ dalam jumlah yang sedikit.

Hasil pengukuran $\mathrm{NO}_{2}$ di 6 titik pengolahan batu kapur Desa Karas Kecamatan Sedan Kabupaten Rembang diperoleh hasil bahwa rata-rata konsentrasi $\mathrm{NO}_{2}$ sebesar 31,64 $\mu \mathrm{g} / \mathrm{Nm}^{3}$. Konsentrasi minimum sebesar 12,41 $\mu \mathrm{g} / \mathrm{Nm}^{3}$ (di titik 6 yaitu zona masyarakat sekitar) dan konsentrasi maksimum 68,86 $\mu \mathrm{g} / \mathrm{Nm}^{3}$ (di titik 2 yaitu tobong 2). Dari data hasil pengukuran terlihat bahwa semua titik di pengolahan batu kapur dan sekitar pengolahan konsentrasinya masih di bawah baku mutu yang ditetapkan pada PP No 41 Tahun 1999 yaitu $400 \mu \mathrm{g} / \mathrm{Nm}^{3}$. Gas $\mathrm{NO}_{2}$ sama dengan $\mathrm{SO}_{2}$ bahwa dalam pembakaran batu kapur dihasilkan dalam jumlah yang sedikit. Hal ini sesuai dengan penelitian yang dilakukan Yulaekah bahwa kadar gas $\mathrm{SO}_{2}$ dan $\mathrm{NO}_{2}$ di industri batu kapur Desa Mrisi Kecamatan Tanggungharjo Kabupaten Grobogan masih di bawah baku mutu.

Pengukuran debu dari 6 titik di pengolahan batu kapur Desa Karas Kec Sedan Kabupaten Rembang diperoleh hasil rata-rata $400,5 \mu \mathrm{g} / \mathrm{Nm}^{3}$ dengan konsentrasi minimum sebesar 144,0 $\mu \mathrm{g} / \mathrm{Nm}^{3}$ (di titik 6 yaitu zona masyarakat sekitar) dan konsentrasi maksimum sebesar 692,4 $\mu \mathrm{g} / \mathrm{Nm} 3$ (di titik 2 yaitu tobong 2). Standar Baku Mutu untuk debu udara ambien menurut PP No 41 Tahun 1999 yaitu $230 \mu \mathrm{g} / \mathrm{Nm}^{3}$, dari hasil pengukuran di 6 titik pengolahan batu kapur dan sekitarnya ternyata hanya 1 yang konsentrasinya di bawah baku mutu yaitu di masyarakat sekitar pengolahan batu kapur yang jaraknya dari pengolahan lebih dari 100 meter. Sedangkan 5 titik lainnya di atas baku mutu hal ini dikarenakan terdapat sifat dinamis lingkungan yang mempengaruhi konsentrasi polutan misalnya yaitu mobilitas, cuaca, kecepatan arah angin, suhu dan kelembaban dan lalu lintas misalnya truk pengangkut batu kapur ke tobong.

Konsentrasi rata-rata hasil pengukuran CO dari 6 titik di pengolahan batu kapur Desa Karas Kecamatan Sedan Kabupaten Rembang adalah $39940 \mu \mathrm{g} / \mathrm{Nm}^{3}$. Konsentrasi minimum adalah $0 \mu \mathrm{g} / \mathrm{Nm}^{3}$ dan konsentrasi maksimum sebesar $133680 \mu \mathrm{g} / \mathrm{Nm}^{3}$. Standar baku yang 
ditetapkan pada PP No 41 Tahun 1999 yaitu $30.000 \mu \mathrm{g} / \mathrm{Nm}^{3}$. Dari 6 titik terdapat 3 titik yang konsentrasinya di bawah baku mutu

Tabel 1. Hasil Pengukuran Emisi Udara di Pengolahan Batu Kapur Desa Karas

\begin{tabular}{|c|c|c|c|c|c|c|c|c|c|}
\hline No & Parameter & Satuan & $\begin{array}{c}\text { Titik } 1 \\
\text { (emisi } \\
\text { zona 1) }\end{array}$ & $\begin{array}{c}\text { Titik } 2 \\
\text { (emisi } \\
\text { zona 2) }\end{array}$ & $\begin{array}{c}\text { Titik } 3 \\
\text { (ambien } \\
\text { zona } 1 \text { dan } \\
\text { 2) }\end{array}$ & $\begin{array}{c}\text { Titik } 4 \\
\text { (emisi } \\
\text { zona 3) }\end{array}$ & $\begin{array}{c}\text { Titik } 5 \\
\text { (ambien } \\
\text { zona 3) }\end{array}$ & $\begin{array}{c}\text { Titik } 6 \\
\text { (udara } \\
\text { ambien) }\end{array}$ & $\begin{array}{l}\text { Baku } \\
\text { Mutu }\end{array}$ \\
\hline \multicolumn{10}{|c|}{ Data Kimia } \\
\hline 1 & $\mathrm{SO}_{2}$ & $\mu \mathrm{g} / \mathrm{Nm}^{3}$ & 2,257 & 6,115 & 1,491 & 0,383 & 0,380 & 0,067 & $632 *)$ \\
\hline 2 & $\mathrm{NO}_{2}$ & $\mu \mathrm{g} / \mathrm{Nm}^{3}$ & 36,59 & 68,86 & 23,35 & 33,73 & 15,18 & 12,41 & 316 \\
\hline 3 & TSP (Debu) & $\mu \mathrm{g} / \mathrm{Nm}^{3}$ & 501,3 & 692,4 & 311,5 & 378,4 & 375,2 & 144,0 & $\begin{array}{l}\left.230^{* * *}\right) \\
30.000\end{array}$ \\
\hline 4 & $\mathrm{CO}$ & $\mu \mathrm{g} / \mathrm{Nm}^{3}$ & 31380 & 69120 & 5220 & 133680 & 240 & 0 & $\begin{array}{c}\mu \mathrm{g} / \mathrm{Nm}^{3} \\
* * * *)\end{array}$ \\
\hline \multirow[t]{2}{*}{5} & Kebisingan & $\mathrm{dB} A$ & 51,79 & 51,69 & 52,85 & 56,38 & 53,01 & 48,78 & $70 * *)$ \\
\hline & Data Fisik & & & & & & & & \\
\hline 1 & Suhu ambien & ${ }^{0} \mathrm{C}$ & 35,5 & 40,5 & 37,5 & 35,5 & 33 & 30 & - \\
\hline 2 & Kelembapan & $\%$ & 37,5 & 36 & 41 & 33 & 59 & 70 & - \\
\hline 3 & $\begin{array}{c}\text { Tekanan } \\
\text { barometer }\end{array}$ & $\mathrm{mmHg}$ & 738 & 737 & 735 & 735 & 735 & 737 & - \\
\hline 4 & Cuaca & - & Cerah & Cerah & Cerah & Cerah & Cerah & Cerah & - \\
\hline 5 & $\begin{array}{l}\text { Kecepatan } \\
\text { Angin }\end{array}$ & $\mathrm{Km} / \mathrm{jam}$ & $1,3-6,8$ & $3,3-7,3$ & $1,6-6,3$ & $6,3-15,1$ & $1,2-14,1$ & $1,4-11,7$ & - \\
\hline 6 & Angin Dari & - & Timur & Utara & Timur & Utara & Timur & Utara & - \\
\hline
\end{tabular}

Keterangan:

*) Baku mutu ambien berdasarkan Kep. Gub Jateng No 8 Tahun 2001 tentang Baku Mutu Udara Ambien di Propinsi Jawa Tengah

Baku Mutu Kebauan berdasarkan Keputusan Menteri Negara Lingkungan Hidup No 50 Tahun 1996 tentang Baku Mutu Tingkat Kebauan

**) Baku Mutu Kebisingan: berdasarkan Keputusan Menteri Negara Lingkungan Hidup No 48 Tahun 1996 Lampiran I tentang Baku Tingkat Kebisingan untuk Kawasan Industri (untuk pengambilan dilakukan 1 jam).

***)Baku Mutu Parameter Pb dan TSP untuk pengambilan 24 jam pengambilan. Untuk hasil analisis dilakukan pengambilan selama 1 jam.

****) Lampiran Peraturan Pemerintah No 41 tahun 1999 tentang Pengendalian Pencemaran Udara Baku Mutu Udara Ambien Nasional

Tabel 2. Rata-rata konsentrasi emisi udara pada 6 titik pengolahan batu kapur Desa Karas Kecamatan Sedan Kabupaten Rembang

\begin{tabular}{ccccc}
\hline Variabel & Rata-rata & Minimum & Maksimum & Baku Mutu \\
\hline $\mathrm{SO}_{2}\left(\mu \mathrm{g} / \mathrm{Nm}^{3}\right)$ & 1,782 & 0,067 & 6,115 & 900 \\
$\mathrm{NO}_{2}\left(\mu \mathrm{g} / \mathrm{Nm}^{3}\right)$ & 31,64 & 12,41 & 68,86 & 400 \\
$\mathrm{Debu}$ & 400,5 & 144,0 & 692,4 & 230 \\
$\left(\mu \mathrm{g} / \mathrm{Nm}^{3}\right)$ & 39940 & 0 & 133680 & 30.000 \\
$\mathrm{CO}\left(\mu \mathrm{g} / \mathrm{Nm}^{3}\right)$ & 3940 \\
$\begin{array}{c}\text { Kebisingan } \\
(\mathrm{db} \mathrm{A})\end{array}$ & 52,42 & 48,78 & 56,38 & 70 \\
\hline
\end{tabular}


Beberapa titik menunjukkan data yang tidak teratur ada yang tinggi dan rendah hal ini dikarenakan terdapat sifat dinamis lingkungan yang mempengaruhi konsentrasi polutan misalnya yaitu kecepatan arah angin, suhu, kelembaban mobilitas, cuaca dan lalu lintas. Proses pembakaran pada pengolahan batu kapur menggunakan bahan bakar dari ban bekas, di mana dalam pembakaran ban bekas menghasilkan gas CO.

Rata-rata konsentrasi kebisingan hasil pengukuran di 6 titik pengolahan batu kapur Desa Karas Kecamatan Sedan Kabupaten Rembang sebesar 52,42 dbA. Konsentrasi minimun sebesar 48,78 db A (di titik 6 yaitu zona masyarakat sekitar) dan konsentrasi maksimum 56,38 dbA (di titik 4 yaitu tobong 3). Dengan demikian rata-rata konsentrasi kebisingan pada 6 titik berada di bawah baku mutu yang ditetapkan pada berdasarkan Keputusan Menteri Negara Lingkungan Hidup No 48 Tahun 1996 tentang Baku Tingkat Kebisingan yaitu 70 dbA. Hasil pengukuran konsentrasi kebisingan dari 6 titik ternyata semua konsentrasinya berada di bawah NAB hal ini dikarenakan dalam pengolahan batu kapur tidak menggunakan mesin-mesin yang menghasilkan suara bising.
Wawancara dengan responden dilaksanakan bertujuan untuk memperoleh data tentang nama, umur, jenis kelamin, masa kerja, lama paparan per hari, riwayat penyakit, tinggi badan, berat badan, data-data tersebut secara teoritis diperkirakan mempunyai pengaruh atau kontribusi terhadap terjadinya penurunan kapasitas vital paru akibat tingginya konsentrasi bahan pencemar di udara. Populasi target pada penelitian ini sebanyak 91 orang dan masyarakat 204 orang. Berdasarkan kriteria yang telah ditetapkan maka hanya responden yang memenuhi syarat saja yang dianalisa. Responden yang memenuhi kriteria sebanyak 73 orang yang terdiri dari 33 pekerja dan 40 masyarakat sekitar. Lama paparan pekerja dalam bekerja rata-rata semua sama yaitu bekerja 12 jam dalam sehari dan berjenis kelamin laki-laki.

Mengingat bahwa penelitian ini hanya membedakan ada penurunan kapasitas vital paru dan tidak ada penurunan kapasitas vital paru, maka tingkatan obstruktif, restriktif dan kombinasi dikelompokkan menjadi ada penurunan kapasitas vital paru. Dengan demikian hasil pengukuran kapasitas vital paru pekerja dan masyarakat sentra pengolahan batu kapur Desa Karas Kecamatan Sedan Kabupaten Rembang dapat dilihat sebagai berikut:

\section{Tabel 3. Distribusi Frekuensi Subjek Penelitian Berdasarkan} Kapasitas Vital Paru Pekerja

Sumber: hasil pengukuran pada tanggal 16 Oktober 2012

\begin{tabular}{ccc}
\hline Kapasitas Vital Paru Pada Pekerja & Frekuensi & Persentase \\
\hline ada penurunan kapasitas vital paru & 24 & 73 \\
tidak ada penurunan kapasitas vital paru & 9 & 27 \\
Jumlah & 33 & 100 \\
\hline
\end{tabular}

Berdasarkan tabel 3, menunjukkan bahwa dari 33 responden yang bekerja di pengolahan batu kapur Desa Karas Kecamatan Sedan Kabupaten Rembang terdapat 24 responden (73\%) mengalami penurunan kapasitas vital paru dan sebanyak 9 responden (27\%) dengan tidak mengalami penurunan kapasitas vital paru. 
Tabel 4. Distribusi Frekuensi Subjek Penelitian Berdasarkan Kapasitas Vital Paru Masyarakat.

\begin{tabular}{ccc}
\hline Fungsi paru pada masyarakat & Frekuensi & Persentase \\
\hline ada penurunan kapasitas vital paru & 9 & 22 \\
tidak ada penurunan kapasitas vital paru & 31 & 78 \\
Jumlah & 40 & 100 \\
\hline
\end{tabular}

Sumber: hasil pengukuran pada tanggal 16 Oktober 2012

Kapasitas Vital Paru pada masyarakat sekitar pengolahan batu kapur Desa Karas Kecamatan Sedan Kabupaten Rembang berdasarkan tabel 4, menunjukkan bahwa dari 40 responden terdapat 9 responden $(22 \%)$ yang mengalami penurunan kapasitas vital paru dan sebanyak 31 responden (78\%) yang tidak mengalami penurunan kapasitas vital paru.

Penelitian ini sesuai dengan penelitian yang dilakukan oleh Bwalya D et al., (2011) pada sebuah pabrik batu kapur di Zambia menyatakan bahwa terdapat pengaruh antara pekerja batu kapur dengan kesehatan pernafasannya. Hasil menunjukkan bahwa paparan debu kapur berpengaruh pada peningkatan gejala gangguan pernafasan.

Variabel bebas yang terdapat pengaruh dengan variabel terikat yaitu kadar debu dan gas CO secara bersamasama dimasukan ke dalam perhitungan uji Odds Ratio untuk mengetahui seberapa besar variabel bebas dalam mempengaruhi variabel terikat. Kedua variabel bebas tersebut dengan hasil $p$ value $\varangle 0,05$ yang berarti mempunyai hubungan yang signifikan terhadap variabel terikat yaitu kapasitas vital paru.

Hasil analisis variabel kadar debu menunjukkan nilai $\mathrm{p}=0,033$ dengan nilai $\mathrm{OR}=1,584$ (1,100-2,283). Hal ini menunjukkan bahwa pekerja dan masyarakat yang terpapar dengan debu di atas NAB

$230 \mu \mathrm{g} / \mathrm{Nm}^{3}$ mempunyai risiko terjadi penurunan kapasitas vital paru sebesar 1 kali lebih tinggi dari masyarakat dengan kadar debu di bawah NAB 230 $\mu \mathrm{g} / \mathrm{Nm}^{3}$. Aditya (2007) menyatakan bahwa pekerja mengalami keluhan subyektif pada saluran pernafasannya akibat paparan debu di tempat kerjanya.

Hasil analisis variabel Gas CO menunjukkan nilai $\mathrm{p}=0,000$ dengan nilai $\mathrm{OR}=2,558(1,100-2,283)$. Hal ini menunjukan bahwa pekerja dan masyarakat yang terpapar dengan debu di atas NAB $30.000 \mu \mathrm{g} / \mathrm{Nm}^{3}$ mempunyai risiko terjadi penurunan kapasitas vital paru sebesar 2 kali lebih tinggi dari masyarakat dengan kadar debu di bawah NAB $30.000 \mu \mathrm{g} / \mathrm{Nm}^{3}$.

Penelitian ini mengacu pada asas lingkungan ke 4, hal ini dikarenakan dalam penggunaan batu kapur sebagai bahan baku dalam sentra pengolahan batu kapur yang secara berlebihan akan tidak menguntungkan lagi. Misalnya dalam pengolahan batu kapur yang berlebihan dapat menyebabkan menurunnya kualitas lingkungan dan terganggunya kesehatan manusia yang merupakan dampak dari kegiatan pengolahan tersebut. Dimana batu kapur merupakan sumber energi di alam yang berasal dari rumah/ cangkang siput dan kerang-kerangan

\section{KESIMPULAN DAN SARAN}

Kesimpulan dari penelitian adalah kualitas udara pada sentra pengolahan batu kapur di Desa Karas Kecamatan Sedan Kabupaten Rembang adalah melebihi baku mutu untuk parameter gas CO dan debu, sedangkan untuk gas $\mathrm{NO}_{2}$ dan $\mathrm{SO}_{2}$ di bawah baku mutu dan terdapat pengaruh antara emisi udara terhadap kapasitas vital paru pada 
pekerja dan masyarakat sentra pengolahan batu kapur di Desa Karas untuk parameter debu dan gas $\mathrm{CO}$, sedangkan $\quad \mathrm{NO}_{2}$ dan $\mathrm{SO}_{2}$ tidak mempengaruhi kapasitas vital paru.

Saran yang direkomendasikan adalah melakukan pemeriksaan kesehatan secara berkala pada pekerja terutama kapasitas vital paru, pemilik tobong sebaiknya menyediakan alat pelindung diri dan melaksanakan pengawasan terhadap kedisiplinan pemakaian, hendaknya bagi Pemerintah dalam hal ini Departemen Tenaga Kerja dan Badan Lingkungan Hidup ikut berperan serta dalam melakukan pengawasan dengan mengadakan kunjungan rutin terhadap industri pengolahan batu kapur untuk mengetahui nilai ambang batas pencemaran dan melakukan pembinaan untuk mengurangi tingkat pencemaran, perlu dilakukan penelitian yang sama pada musim hujan, karena penelitian ini dilakukan pada musim kemarau dan sebaiknya dalam pembuatan tobong berjarak lebih dari 100 meter dari pemukiman penduduk. Melakukan penelitian yang sama pada musim hujan, karena penelitian ini dilakukan pada musim kemarau dan pemeriksaan kadar CO dalam darah. Sebaiknya tinggi tungku pengolahan batu kapur ditambah 2 - 2,5 kali dari tinggi bangunan sekitarnya atau pemukiman penduduk

\section{REFERENSI}

Aditya SA., dan Denny A. 2007. Identifikasi Kadar Debu Di Lingkungan Kerja Dan Keluhan Subyektif Pernafasan Tenaga Kerja Bagian Finish Mill. Jurnal Kesehatan Lingkungan, Vol 162 L.3, NO.2,161 - 172.

Aditama, T.Y. 1992. Polusi Udara Dan Kesehatan. ARCAN.

Bwalya D, Bråtveit M, Moen BE. 2011. Chronic Respiratory Symptoms Among Workers At A Limestone Factory In Zambia. Department for Public Health and Primary
Health Care, University of Bergen, Bergen, Norway. Archives of Environmental \& Occupational Health. Vol. 66, No. 1, 47-50.

Chattopadhyay BP, Roychowdhury A, Alam J, Kundu S. 2005. Respiratory Health Status of the Roadside School Children at Kolkata.J Environ Sci Eng. Vol 47 No 3: P 202-11.

Keputusan Menteri Negara

Kependudukan Dan Lingkungan

Hidup Nomor: KEP-

02/ MENKLH/ I/ 1988. Pedoman

Penetapan Baku Mutu

Lingkungan.

Kristanto, P. 2001. Ekologi Industri. Yogyakarta: ANDI.

Peraturan Pemerintah Republik Indonesia. 1999. Pengendalian Pencemaran Udara. PP Nomor 41 Tahun 1999.

Sugiarti. 2009. Gas Pencemar Udara Dan Pengaruhnya Bagi Kesehatan Manusia. Jurnal Chemical Vol. 10 Nomor 1, 50-58.

Sugiyono. 2002. Statistika untuk Penelitian. Bandung: Alfabeta.

Subijanto A.A. 2008. Area Industri Gamping Sebagai Faktor Risiko Gangguan Fungsi Paru. Berita Kedokteran Masyarakat. Vol. 24, No 2, Juni, Hal 86-89.

Yulaekah, S. 2007. Paparan Debu Terhirup Dan Gangguan Fungsi Paru Pada Pekerja Industri Batu Kapur (Studi Di Desa Mrisi Kecamatan Tanggungharjo Kabupaten Grobogan). [Tesis]. Semarang: Program Pascasarjana UNDIP. 